\title{
Other Establishment Activity
}

National Cancer Institute

\section{Source}

National Cancer Institute. Other Establishment Activity. NCI Thesaurus. Code C123269.

The establishment activity is other than that which already appears in the establishment activity value set. 